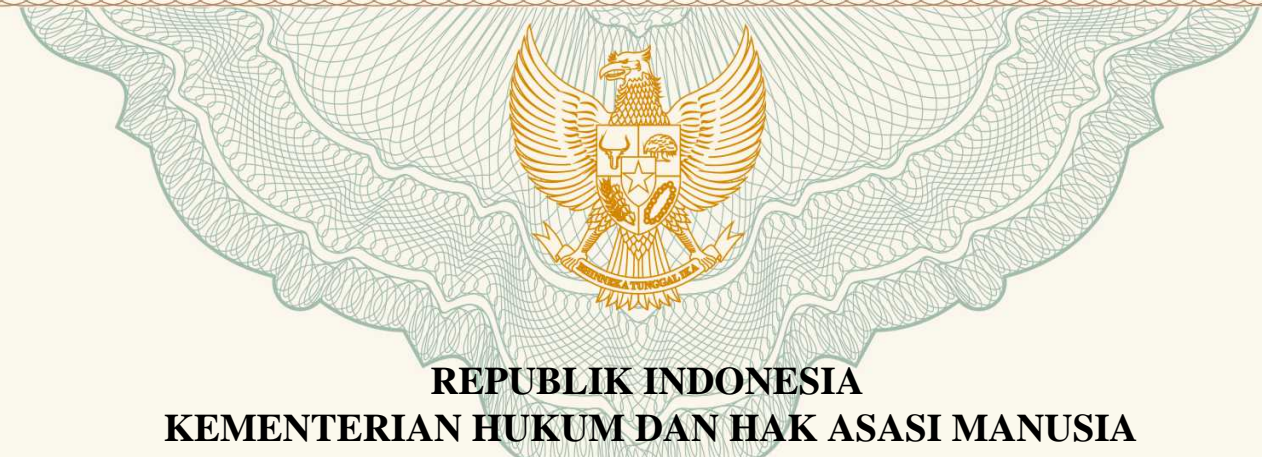

KEMENTERIAN HUKUM DAN HAK ASASI MANUSIA

\title{
SURAT PENCATATAN CIPTAAN
}

Dalam rangka pelindungan ciptaan di bidang ilmu pengetahuan, seni dan sastra berdasarkan Undang-Undang Nomor 28 Tahun 2014 tentang Hak Cipta, dengan ini menerangkan:

Nomor dan tanggal permohonan

EC00201947291, 24 Juli 2019

Pencipta

Nama

Alamat

Dr. Hj. Beti Nurbaiti, STP.,ME

Kewarganegaraan

J1. Sabut Blok E No. 17-19, RT. 09/RW. 011, Kavling PTB DKI Pondok Kelapa, Jakarta Timur, Jakarta, Dki Jakarta, 13450

Pemegang Hak Cipta

Nama

Indonesia

Alamat

\section{Dr. Hj. Beti Nurbaiti, STP.,ME}

Jl. Sabut Blok E No. 17-19, RT. 09/RW. 011, Kavling PTB DKI Pondok Kelapa, Jakarta Timur, Jakarta, Dki Jakarta, 13450

Kewarganegaraan

Indonesia

Jenis Ciptaan

Modul

Judul Ciptaan

MODUL PENGOLAHAN DATA DENGAN LISREL

Tanggal dan tempat diumumkan untuk pertama 23 Juli 2019, di Jakarta

kali di wilayah Indonesia atau di luar wilayah Indonesia

Jangka waktu pelindungan

Berlaku selama hidup Pencipta dan terus berlangsung selama 70 (tujuh puluh) tahun setelah Pencipta meninggal dunia, terhitung mulai tanggal 1 Januari tahun berikutnya.

Nomor pencatatan

000147487

adalah benar berdasarkan keterangan yang diberikan oleh Pemohon.

Surat Pencatatan Hak Cipta atau produk Hak terkait ini sesuai dengan Pasal 72 Undang-Undang Nomor 28 Tahun 2014 tentang Hak Cipta.

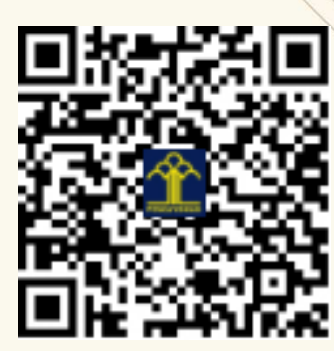

a.n. MENTERI HUKUM DAN HAK ASASI MANUSIA DIREKTUR JENDERAL KEKAYAAN INTELEKTUAL

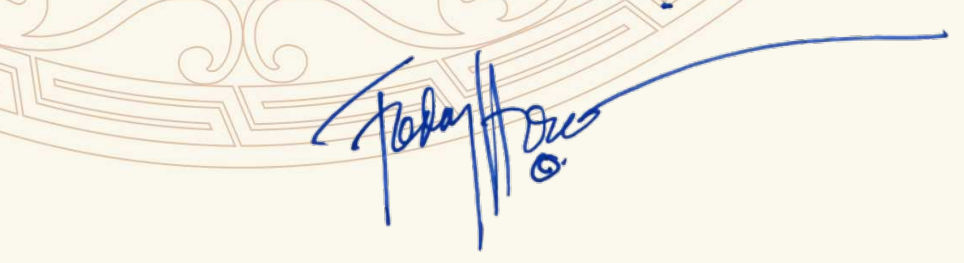

Dr. Freddy Harris, S.H., LL.M., ACCS.

NIP. 196611181994031001 